\section{Cureus}

Received 03/08/2018

Review began 03/08/2018

Review ended 03/08/2018

Published 03/12/2018

\section{(C) Copyright 2018}

Akhtar et al. This is an open access article distributed under the terms of the Creative Commons Attribution License CC-BY 3.0., which permits unrestricted use, distribution, and reproduction in any medium, provided the original author and source are credited.

\title{
Gastric Volvulus: A Rare Entity Case Report and Literature Review
}

\author{
Aisha Akhtar ${ }^{1}$, Fasih Sami Siddiqui ${ }^{2}$, Abdul Ahad E. Sheikh ${ }^{3}$, Abu Baker Sheikh ${ }^{4}$, Abhilash \\ Perisetti ${ }^{5}$
}

1. Surgery, Texas Tech University Health Sciences Center, Lubbock, USA 2. Internal Medicine, Shifa College of Medicine, Islamabad, PAK 3. Internal Medicine, Shifa International Hospital, Islamabad, PAK 4. Internal Medicine, University of New Mexico, Albuquerque, USA 5. Internal Medicine/

Gastroenterology, University of Arkansas for Medical Sciences, Little Rock, USA

$\square$ Corresponding author: Fasih Sami Siddiqui, fasih.s.siddiqui@gmail.com

Disclosures can be found in Additional Information at the end of the article

\section{Abstract}

Gastric volvulus is a rare entity defined as an abnormal rotation of the stomach around itself. It is a diagnosis of exclusion; the clinical index of suspicion is always low and is mostly diagnosed on imaging or on the surgery table. When it occurs, it is an emergency due to the risk of strangulation and consequent gangrene of the stomach. Mesentero-axial (MA) gastric volvuli constitute one-third of all cases. Here, we are present an interesting case of acute MA gastric volvulus diagnosed with imaging and treated subsequently.

Categories: Emergency Medicine, Gastroenterology, General Surgery

Keywords: gastric volvulus, mesenteroaxial volvulus, small bowel obstruction

\section{Introduction And Background}

Gastric volvulus is a rare entity defined as an abnormal rotation of the stomach around itself. Berti was the first to describe it in 1866 as an autopsy finding, and Berg was the first to successfully treat it surgically in 1897 [1]. Gastric volvulus is characterized by an abnormal rotation of the stomach around its short or long axis leading to variable degrees of gastric inlet and outlet obstruction. A rotation of more than 180 degrees can cause strangulation, necrosis, and finally perforation; hence, it is a surgical emergency. Acute mesentero-axial (MA) volvulus is more common in children and young adults, with few cases reported in the elderly. Due to advances in diagnosis and management, the mortality from acute gastric volvulus is now 15\%$20 \%$, and that for chronic gastric volvulus is $0 \%-13 \%$ [2]. Acute idiopathic gastric volvulus in the elderly is a rare entity. We present this case because it is an uncommon life-threatening disease. Given its rarity and unusual presentation, the clinical index of suspicion is always low. Gastric volvulus is mostly diagnosed on imaging or on the surgery table.

\section{Review}

\section{Case}

A 68-year-old male presented for an evaluation of small bowel obstruction. He had a prior medical history of hypertension and chronic pancreatitis diagnosed four years ago and a surgical history of left total knee arthroplasty, followed by a revision three weeks ago (was residing at a nursing home for rehabilitation). The patient reported a one-day history of epigastric pain, generalized abdominal discomfort, distension, along with an eight-day history of constipation. He was passing flatus and also noticed progressive worsening abdominal 


\section{Cureus}

distension for the past two days with uncontrollable belching and retching, but denied any vomiting or fever. He was given laxative enemas at the nursing home for his constipation and had a subsequent bowel movement, after which he developed abdominal pain. He was taken to a nearby hospital where an X-ray of the abdomen was performed which showed a huge distended stomach with the nasogastric tube (NG) coiled up in the esophagus (Figure 1). Computed tomography (CT) scan of the abdomen showed huge gastric distension with no free fluid or air.

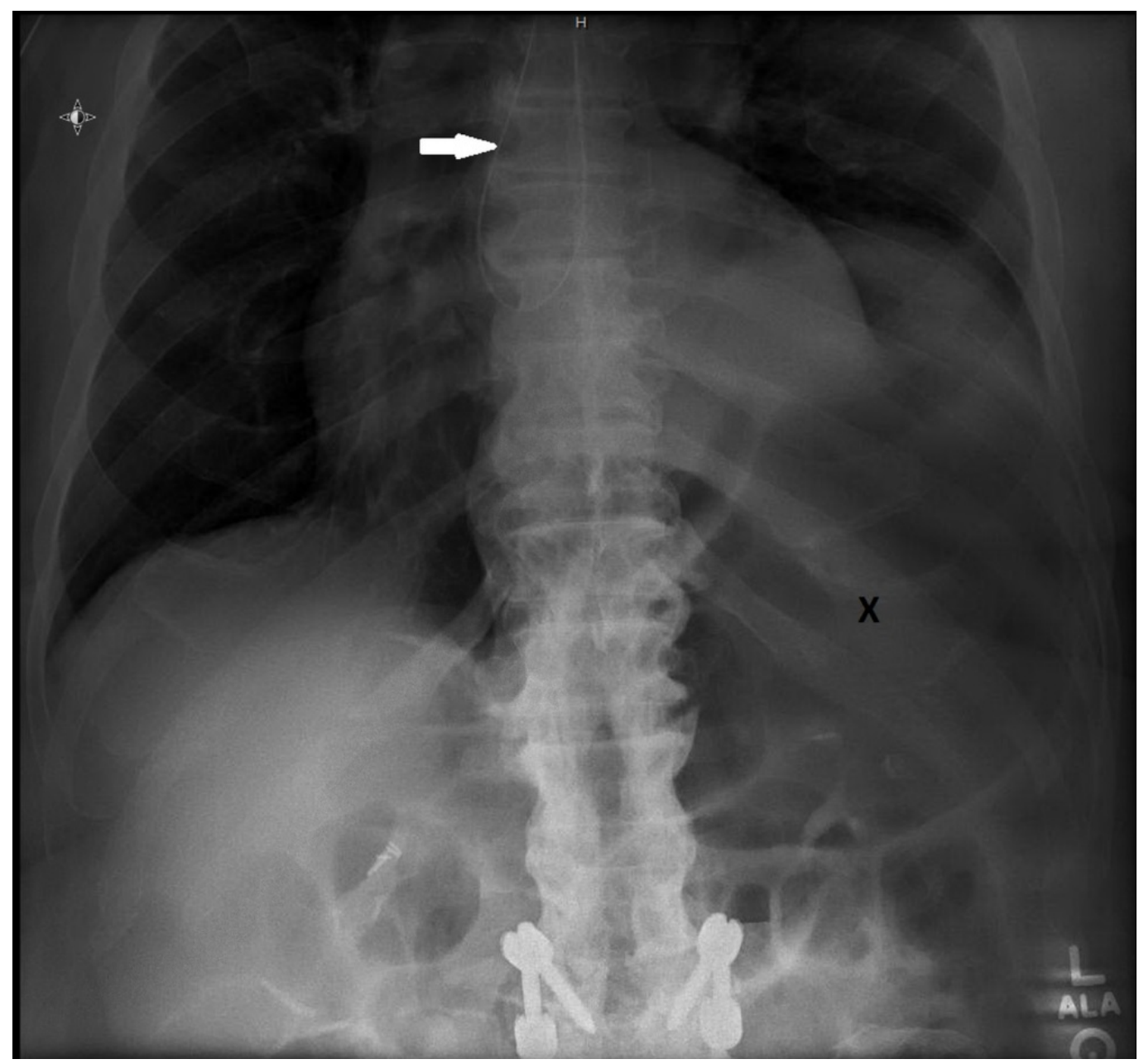

\section{FIGURE 1: X-ray of the patient showing the nasogastric tube coiled up in the esophagus (white arrow) with a huge distended stomach (letter $\mathrm{X}$ )}

On presentation at our hospital, the patient was still complaining of epigastric pain, retching, and belching. On physical examination, the patient was in slight distress. Oxygen saturation on pulse oximetry was $97 \%$, blood pressure (BP) was $132 / 75 \mathrm{mmHg}$ while supine, heart rate was 97/min, and the temperature was 97.4 degrees Fahrenheit. He was alert and oriented times three. There was no conjunctival pallor. The pupils were about $4 \mathrm{~mm}$ bilaterally and reactive to light. On auscultation, he had dual heart sounds with no murmurs noted. Breath sounds were bilaterally equal with no crackles or rhonchi. The abdomen was soft, non-tender, mildly distended with no masses noted.

Laboratory testing revealed a slightly elevated white blood cell (WBC) count of $12.8 \mathrm{~K} / \mathrm{uL}$, hemoglobin of $10.5 \mathrm{~g} / \mathrm{dL}$, and a platelet count of 262,000/uL. Electrolytes were within normal 


\section{Cureus}

limits. Chest X-ray showed NG in the esophagus which was advanced into the stomach under fluoroscopy. X-ray of the abdomen showed ileus. He was afebrile, non-septic, and treated conservatively for one day, but his symptoms didn’t resolve. A small bowel follow-through study was performed which showed MA gastric volvulus with the antrum displaced above the gastroesophageal junction as best demonstrated in Figure 2. The small bowel showed normal caliber and the fold pattern was unremarkable. Only a small amount of contrast would pass beyond the stomach due to the volvulus. A subsequent CT scan confirmed the displacement of the antrum above the gastroesophageal junction; the stomach appeared upside-down with the antrum and pylorus superior to the fundus and proximal body (Figure 3). He was taken to the operating room where MA gastric volvulus was visually confirmed with the stomach rotated and its greater curvature adherent to the under-surface of the diaphragm. After releasing the stomach from its adherence, gastropexy was done on the right side and a g-tube was placed on the left side. Postoperative recovery was uneventful and the patient returned to his rehabilitation facility on the fourth post-operative day.

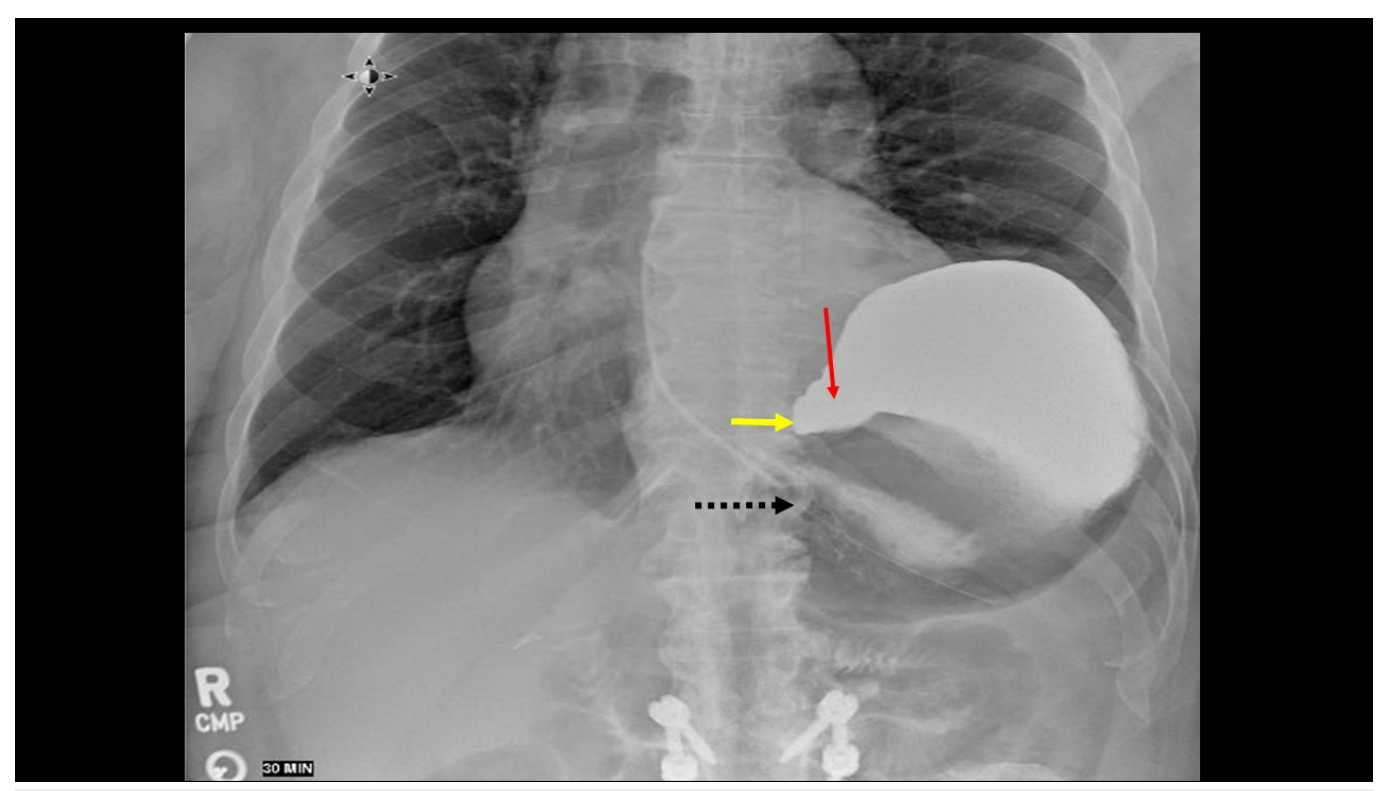

FIGURE 2: Small bowel of the patient showing the antrum (red arrow) and pylorus (yellow arrow) displaced above the gastroesophageal junction (black dotted arrow) 


\section{Cureus}

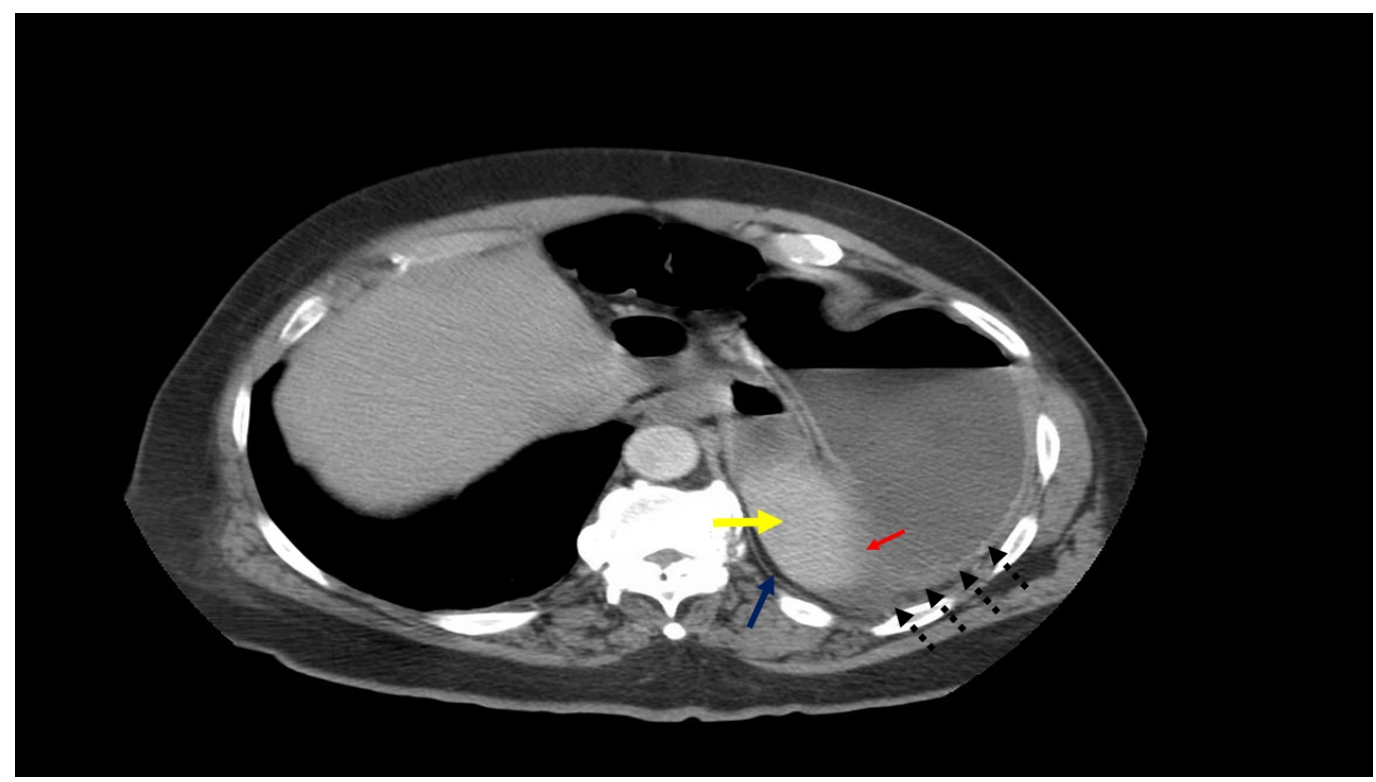

\section{FIGURE 3: Computed tomography scan of the stomach}

The stomach appears upside-down with the antrum (red arrow) and pylorus (yellow arrow) superior to the fundus (blue arrow) and proximal body (black dotted arrows).

\section{Discussion}

The term "volvulus" is derived from Latin volvere, which means to turn or roll. Gastric volvulus is a rare entity that was first described by Berti during an autopsy in 1866. It was successfully treated surgically for the first time in 1897 by Berg [1].

Gastric volvulus is characterized by the rotation of the stomach along its short or long axis leading to a variable degree of gastric inlet and outlet obstruction. Rotation more than 180 degrees can lead to strangulation, necrosis, and finally perforation. Hence, it is a surgical emergency. Acute MA volvulus is more common in children; however, a few reports on adults do exist.

Gastric volvulus has been classified based on both etiology (primary or secondary) and the axis of rotation, but the most accepted classification of volvuli is according to the latter as proposed by Singleton [3].

Type I is organo-axial (OA) volvulus (rotation around an axis connecting the pylorus and cardio-esophageal junction; it occurs in 59\% of the cases). Type II is (MA) volvulus (rotation around the axis causing bisection of greater and lesser curvature of the stomach; it occurs in $29 \%$ of the cases). Type III is a combination of OA and MA (occurs in $2 \%$ of cases) and type IV is unclassified (occurs in $10 \%$ of cases) [4].

It can also be classified based on etiology as primary/idiopathic volvulus (associated with tumors, adhesions, the or problems in the normal ligamentous attachments of stomach), or secondary volvulus (associated with disorders of gastric motility and anatomy, or with issues of neighboring structures like the diaphragm and spleen) [5]. Most cases of gastric volvulus have a secondary cause. Diseases of the stomach, like peptic ulcers, retract the small curvature and predispose the stomach to MA axis rotation. In adults, secondary gastric volvulus is usually associated with para-esophageal hernia and traumatic diaphragm injury. 


\section{Cureus}

Typically, MA gastric volvulus is very rare in the elderly and is mostly reported in young adults and children. The etiology is idiopathic, with an elevation of the left hemi-diaphragm and a peritoneal adhesion band of unknown origin.

The presentation of gastric volvulus can be acute, subacute, or chronic. The classical Borchardt triad of retching, severe epigastric pain, and inability to pass NG tube hold true for gastric volvulus, most of the time, when it presents acutely like in our case. Subacute presentation is associated with vague abdominal pain [5]. An MA volvulus usually presents as a chronic disease.

Diagnosis of gastric volvulus is challenging due to the non-specificity of the symptoms and rarity of the condition; it is usually achieved radiologically in combination with the clinical presentation. Plain radiographs may show two air-fluid levels in the antrum and fundus, or a single air bubble with no additional luminal gas in the supine position, and a 'beak' in the cardio-esophageal region. Abdominal CT scan is very accurate in diagnosing volvulus; it shows an upside-down stomach with the pylorus higher than gastro-esophageal junction. Upper gastrointestinal series is also a useful tool [6]. Teague et al. reported (in a study including 36 patients with gastric volvulus) that barium contrast studies were helpful in $84 \%$ of the 25 patients who underwent this investigation [7]. As gastric volvulus is rarely suspected according to the clinical symptoms, barium studies are usually conducted as a first-line investigation, and most patients undergo an abdominal CT scan to confirm the diagnosis.

Initial management is nasogastric decompression to decrease the intragastric pressure followed by surgery to check gastric viability, resect gangrenous portion, and perform de-rotation and gastropexy with or without gastrostomy with repair of secondary factors. Emergent laparotomy is still the most common surgical option for patients with gastric volvulus, though laparoscopic interventions have been described. Surgical reduction with or without gastropexy is the most frequently performed procedure [6].

Jacob et al. reviewed 38 cases of gastric volvulus from 1968 to 2001; he reported that occurrences of gastric volvulus are mainly secondary (75.8\%); $52.6 \%$ of volvuli observed was OA type and $18.4 \%$ was of MA type. Surgery was chosen as the treatment option for the majority of patients (33 out of 38), with conservative treatment reserved only for patients who were unfit to undergo surgery [5].

In our patient gastropexy was done on the right side and a g-tube was placed on the left side; postoperative recovery was uneventful.

We searched the literature and conducted a review of all the cases reported from 1999 to 2018 using PubMed. Details such as demographic data, clinical presentation, type of gastric volvulus, diagnostic test, etiology, treatment, and outcome were obtained. Cases which failed to mention this information were excluded. We found 43 case-reports on this topic which are summarized in Tables 1 .

\begin{tabular}{|c|c|c|c|c|c|c|c|c|}
\hline PUBLICATION & AGE & SEX & Clinical presentation & Type & Dx & $\mathbf{R x}$ & Etiology & Recovery \\
\hline Palanivelu [2] & 23 & $\mathrm{~F}$ & $\begin{array}{l}\text { Pregnant, epigastric pain, } \\
\text { vomiting, dyspnea, oliguria }\end{array}$ & $\mathrm{OA}$ & CT & Surgical & Hiatal hernia & Uneventful \\
\hline Jabbour [4] & 23 & M & $\begin{array}{l}\text { Vomiting, epigastric pain, } \\
\text { distension, constipation }\end{array}$ & MA & CT & Surgical & Idiopathic & Uneventful \\
\hline Nunes [8] & 75 & $\mathrm{~F}$ & $\begin{array}{l}\text { Abdominal pain and coffee ground } \\
\text { emesis }\end{array}$ & $\mathrm{OA}$ & CT & Surgical & Hiatal hernia & Uneventful \\
\hline
\end{tabular}




\section{Cureus}

\begin{tabular}{|c|c|c|c|c|c|c|c|c|}
\hline Patel [9] & 61 & $\mathrm{~F}$ & $\begin{array}{l}\text { Worsening localised left sided } \\
\text { burning, substernal chest pain, } \\
\text { Nausea, vomiting and dyspnea }\end{array}$ & OA & CT & Surgical & $\begin{array}{l}\text { Paraesophageal } \\
\text { hernia }\end{array}$ & Uneventful \\
\hline Omata [10] & 43 & $\mathrm{~F}$ & $\begin{array}{l}\text { Abdominal pain with fullness and } \\
\text { vomiting }\end{array}$ & MA & GI series & $\begin{array}{l}\text { Endoscopic } \\
\text { reduction then } \\
\text { surgery }\end{array}$ & Idiopathic & Uneventful \\
\hline Arima [11] & 50 & M & Acute abdominal pain & MA & CT & Surgical & Idiopathic & Uneventful \\
\hline Al-Naami [12] & 34 & $\mathrm{M}$ & $\begin{array}{l}\text { Epigastric pain, dyspepsia, weight } \\
\text { loss }\end{array}$ & OA & $\begin{array}{l}\text { Barium } \\
\text { swallow }\end{array}$ & Surgical & $\begin{array}{l}\text { Traumatic } \\
\text { diaphragmatic } \\
\text { hernia (Gunshot) }\end{array}$ & Uneventful \\
\hline Lee [13] & 79 & $\mathrm{~F}$ & $\begin{array}{l}\text { Recurrent epigastric pain and } \\
\text { nausea }\end{array}$ & MA & CT & Surgical & Idiopathic & Uneventful \\
\hline Atef [14] & 56 & $\mathrm{~F}$ & $\begin{array}{l}\text { Epigastric pain with early satiety } \\
\text { and postprandial vomiting, } \\
\text { dyspnea }\end{array}$ & OA & $\begin{array}{l}\text { Barrium } \\
\text { Swallow }\end{array}$ & Surgical & $\begin{array}{l}\text { Bochdalek hernia, } \\
\text { Diaphragmatic } \\
\text { hernia }\end{array}$ & Uneventful \\
\hline LIN [15] & 36 & M & $\begin{array}{l}\text { Massive hemetemesis, } \\
\text { postprandial abdominal pain and } \\
\text { vomiting }\end{array}$ & MA & $\mathrm{CT}$ & Surgical & $\begin{array}{l}\text { Paraesophageal } \\
\text { hernia }\end{array}$ & Uneventful \\
\hline $\begin{array}{l}\text { Masjedizadeh } \\
\text { [16] }\end{array}$ & 52 & M & Recurrent vomiting & OA & CT & Surgical & Sliding hiatal hernia & Uneventful \\
\hline $\begin{array}{l}\text { Karthikeyan } \\
\text { [17] }\end{array}$ & 38 & $\mathrm{~F}$ & $\begin{array}{l}\text { Upper abdominal pain >> } \\
\text { diagnostic EGD performed >> } \\
\text { increased severity of abdominal } \\
\text { pain and distension }\end{array}$ & OA & Laparotomy & Surgical & $\begin{array}{l}\text { latrogenic (following } \\
\text { EGD) }\end{array}$ & Uneventful \\
\hline $\begin{array}{l}\text { Martinez-Perez } \\
{[18]}\end{array}$ & 77 & $\mathrm{~F}$ & Acute abdominal pain & $\mathrm{OA}$ & CT & Surgical & Hiatal hernia & Died \\
\hline Kosai [19] & 79 & $\mathrm{~F}$ & $\begin{array}{l}\text { Incarcerated incisional hernia, } \\
\text { abdominal pain, nausea, vomiting }\end{array}$ & OA & CT & Surgical & Hiatal hernia & Uneventful \\
\hline Black [20] & 70 & $\mathrm{~F}$ & Abdominal pain with nausea & OA & CT & Surgical & $\begin{array}{l}\text { Paraesophageal } \\
\text { hernia }\end{array}$ & Uneventful \\
\hline Altintoprak [21] & 19 & M & $\begin{array}{l}\text { Severe abdominal pain and } \\
\text { vomiting }\end{array}$ & MA & CT & Surgical & Idiopathic & Died \\
\hline Altintoprak [21] & 60 & $\mathrm{~F}$ & $\begin{array}{l}\text { Nausea and Vomiting, Inability to } \\
\text { urinate }\end{array}$ & MA & CT & Surgical & $\begin{array}{l}\text { Diaphragmatic } \\
\text { hernia }\end{array}$ & Uneventful \\
\hline Kilincalp [22] & 25 & M & $\begin{array}{l}\text { Severe abdominal pain and } \\
\text { retching }\end{array}$ & MA & CT & $\begin{array}{l}\text { Endoscopic } \\
\text { decompression }\end{array}$ & Postural deformity & Uneventful \\
\hline Lianos [23] & 28 & $\mathrm{~F}$ & $\begin{array}{l}\text { Acute Severe abdominal pain, } \\
\text { nausea, and multiple episodes of } \\
\text { bilious vomiting }\end{array}$ & MA & laparotomy & Surgical & Idiopathic & Uneventful \\
\hline Jeong [24] & 50 & $\mathrm{M}$ & Acute epigastric pain & MA & CT & Surgical & Idiopathic & Uneventful \\
\hline
\end{tabular}




\section{Cureus}

\begin{tabular}{|c|c|c|c|c|c|c|c|c|}
\hline Ooka [25] & 22 & M & Acute abdominal pain & MA & CT & Surgical & Idiopathic & Uneventful \\
\hline Sultan [26] & 51 & $\mathrm{M}$ & $\begin{array}{l}\text { Epigastric pain with Nausea and } \\
\text { vomiting }\end{array}$ & MA & Laproscopy & Surgical & $\begin{array}{l}\text { Stomach adherent } \\
\text { to a chronically } \\
\text { inflamed gall } \\
\text { bladder }\end{array}$ & Uneventful \\
\hline Kang [27] & 22 & $\mathrm{M}$ & $\begin{array}{l}\text { Abdominal pain with nausea and } \\
\text { vomiting }\end{array}$ & MA & $\begin{array}{l}\text { Upper GI } \\
\text { series }\end{array}$ & Surgical & Idiopathic & Uneventful \\
\hline Warren [28] & 72 & $\mathrm{~F}$ & $\begin{array}{l}\text { Acute nausea, acute abdominal } \\
\text { pain, retching, distension }\end{array}$ & OA & $\begin{array}{l}\text { Emergency } \\
\text { Endoscopy }\end{array}$ & Surgical & Hiatal hernia & Uneventful \\
\hline Larssen [29] & 75 & $\mathrm{~F}$ & Acute chest pain and Bradycardia & OA & Laparoscopy & Surgical & Hiatal hernia & $\begin{array}{l}\text { Pot-Op } \\
\text { low } \\
\text { Nutritional } \\
\text { intake and } \\
\text { dumping } \\
\text { syndrome }\end{array}$ \\
\hline Larssen [29] & 90 & $\mathrm{M}$ & Hematemesis and fever & OA & CT & Surgical & Hiatal hernia & Uneventful \\
\hline Larssen [29] & 49 & $\mathrm{M}$ & $\begin{array}{l}\text { Acute epigastric pain and } \\
\text { hematemesis }\end{array}$ & MA & CT & Surgical & Hiatal hernia & Uneventful \\
\hline Nayak [30] & & $\mathrm{M}$ & $\begin{array}{l}\text { repeated episodes of non-bilious } \\
\text { vomiting and epigastric pain }\end{array}$ & MA & CT & Surgical & $\begin{array}{l}\text { Congenital } \\
\text { diaphragmatic } \\
\text { hernia and h/o } \\
\text { Blunt abdominal } \\
\text { trauma }\end{array}$ & Uneventful \\
\hline Tabib [31] & 75 & $\mathrm{M}$ & $\begin{array}{l}\text { epigastric pain, nausea, and } \\
\text { hematemesis }\end{array}$ & $\mathrm{OA}$ & $\begin{array}{l}\text { Barium } \\
\text { swallow }\end{array}$ & Surgical & Hiatal hernia & Uneventful \\
\hline Chen [32] & 83 & $\mathrm{~F}$ & Vomiting, chest discomfort & OA & CT scan & Surgical & $\begin{array}{l}\text { Supradiaphragmatic } \\
\text { hernia }\end{array}$ & Uneventful \\
\hline Ghatak [33] & 49 & $\mathrm{~F}$ & $\begin{array}{l}\text { Weight loss, mild epigastric pain, } \\
\text { heartburn, anorexia }\end{array}$ & MA & Barium + CT & Surgical & Idiopathic & Uneventful \\
\hline Fansur [34] & 80 & $\mathrm{~F}$ & $\begin{array}{l}\text { Dull epigastric ache and } \\
\text { postprandial bloating }\end{array}$ & MA & Barium + CT & $\begin{array}{l}\text { Conservative } \\
\text { (Patient unfit } \\
\text { for surgery) }\end{array}$ & $\begin{array}{l}\text { Morgagni } \\
\text { Diaphragmatic } \\
\text { Hernia }\end{array}$ & Uneventful \\
\hline Kim [35] & 49 & $\mathrm{~F}$ & $\begin{array}{l}\text { Acute epigastric soreness and } \\
\text { vomiting }\end{array}$ & $\mathrm{OA}$ & CT & Surgical & Idiopathic & Uneventful \\
\hline Germanos [36] & 62 & $\mathrm{M}$ & $\begin{array}{l}\text { Acute severe upper abdominal } \\
\text { pain }\end{array}$ & OA & Gatrograffin & Surgical & Hiatal hernia & Uneventful \\
\hline $\begin{array}{l}\text { Yakaryilmaz } \\
\text { [37] }\end{array}$ & 26 & $\mathrm{M}$ & $\begin{array}{l}\text { Epigastric pain with Nausea and } \\
\text { vomiting }\end{array}$ & $\mathrm{OA}$ & CT scan & Surgical & Hiatal hernia & Uneventful \\
\hline Iso [38] & 86 & $\mathrm{~F}$ & Black tarry Stools & $\mathrm{OA}$ & CT & Surgical & Hiatal hernia & Uneventful \\
\hline Singham [39] & 81 & $\mathrm{~F}$ & Acute hematemesis and severe & MA & CT & Expired before & Paraoesophage & Died \\
\hline
\end{tabular}




\section{Cureus}

\begin{tabular}{|c|c|c|c|c|c|c|c|c|}
\hline & & & epigastric pain & & & surgery & hernia & \\
\hline Sung [40] & 70 & $\mathrm{~F}$ & $\begin{array}{l}\text { Left sided chest pain, non-bilious } \\
\text { vomiting and shortness of breath }\end{array}$ & MA & CT scan & Surgical & $\begin{array}{l}\text { Diaphragmatic } \\
\text { hernia }\end{array}$ & Uneventful \\
\hline Woon [41] & 73 & M & Atypical chest and epigastric pain & MA & CT & Surgical & Idiopathic & Uneventful \\
\hline Coulier [42] & 79 & $\mathrm{~F}$ & $\begin{array}{l}\text { Epigastric and left upper } \\
\text { abdominal pain with Nausea and } \\
\text { vomiting }\end{array}$ & MA & CT scan & Surgical & Idiopathic & Uneventful \\
\hline Testini [43] & 51 & $\mathrm{M}$ & $\begin{array}{l}\text { Gastric pain, dyspnea, nausea, } \\
\text { vomiting }\end{array}$ & OA & CT & Surgical & $\begin{array}{l}\text { latrogenic } \\
\text { diahragmatic hernia }\end{array}$ & Uneventful \\
\hline Shriki [44] & 75 & $\mathrm{~F}$ & Chest pain, SOB, hypotension & MA & CT & Surgical & $\begin{array}{l}\text { Paraesophageal } \\
\text { hernia }\end{array}$ & Uneventful \\
\hline Matsuzaki [45] & 81 & $\mathrm{~F}$ & Painless postprandial vomiting & C & $\begin{array}{l}\text { Barium } \\
\text { swallow }\end{array}$ & $\begin{array}{l}\text { Conservative } \\
\text { (surgery } \\
\text { refused) }\end{array}$ & Idiopathic & Uneventful \\
\hline Our Case & 68 & $\mathrm{M}$ & $\begin{array}{l}\text { epigastric pain, generalized } \\
\text { abdominal discomfort, distension } \\
\text { and constipation }\end{array}$ & MA & $\begin{array}{l}\text { Barium } \\
\text { swallow }\end{array}$ & Surgical & Idiopathic & Uneventful \\
\hline
\end{tabular}

TABLE 1: Literature review of all the gastric volvulus cases reported from 1999 to 2018, utilizing PubMed

M: male; F: female; MA: mesentaro-axial; OA: organo-axial; C: combine mesentaro-axial and organoaxial; Dx: diagnosis; Rx: treatment.

In our literature review, organo-axial type was reported in $46.5 \%$ of the cases and the MA type was reported in $51.1 \%$ of the cases. Gastric volvulus due to secondary cause was found in $67.4 \%$ of the cases. Surgery was the mainstay of treatment in $90.7 \%$ of the patients. Death was reported in only three cases and rest of the patients recovered uneventfully.

\section{Conclusions}

Acute gastric volvulus is a surgical emergency with high morbidity and mortality. The most important factor in diagnosing acute volvulus of the stomach is a high index of suspicion. A constellation of clinical symptoms along with radiological studies helps in making the diagnosis. Emergency laparotomy is needed to prevent serious complications like gangrene and perforation.

\section{Additional Information \\ Disclosures}

Conflicts of interest: In compliance with the ICMJE uniform disclosure form, all authors declare the following: Payment/services info: All authors have declared that no financial support was received from any organization for the submitted work. Financial relationships: All authors have declared that they have no financial relationships at present or within the previous three years with any organizations that might have an interest in the submitted work. 
Other relationships: All authors have declared that there are no other relationships or activities that could appear to have influenced the submitted work.

\section{References}

1. Carter R, Brewer LA, Hinshaw DB: Acute gastric volvulus. A study of 25 cases . Am J Surg. 1980, 140:99-106. 10.1016/0002-9610(80)90424-9

2. Palanivelu C, Rangarajan M, Shetty AR: Laparoscopic suture gastropexy for gastric volvulus: a report of 14 cases. Surg Endosc. 2007, 21:863-6. 10.1007/s00464-006-9089-4

3. Singleton AC: Chronic gastric volvulus. Radiology. 1940, 34:53-61. 10.1148/34.1.53

4. Jabbour G, Afifi I, Ellabib M: Spontaneous acute mesenteroaxial gastric volvulus diagnosed by computed tomography scan in a young man. Am J Case Rep. 2016, 17:283-8. 10.12659/ajcr.896888

5. Jacob EC, Lopasso PF: Gastric volvulus: A review of 38 cases . Arq Bras Cir Dig. 2009, 22:96100. 10.1590/S0102-67202009000200006

6. Rashid F, Thangarajah T, Mulvey D: A review article on gastric volvulus: a challenge to diagnosis and management. Int J Surg. 2010, 8:18-24. 10.1016/j.ijsu.2009.11.002

7. Teague WJ, Ackroyd R, Watson DI: Changing patterns in the management of gastric volvulus over 14 years. Br J Surg. 2000, 87:358-61. 10.1046/j.1365-2168.2000.01385.X

8. Nunes G, Patita M, Fernandes V: Paraesophageal hernia and gastric volvulus: an uncommon etiology of vomiting and upper gastrointestinal bleeding. Rev Esp Enferm Dig. 2017, 109:294295.

9. Patel JB, Akshintala D, Patel P: Intermittent gastric volvulus mimicking acute coronary syndrome. Am J Med. 2017, 130:e47-e49. 10.1016/j.amjmed.2016.06.055

10. Omata J, Utsunomiya K, Kajiwara Y: Acute gastric volvulus associated with wandering spleen in an adult treated laparoscopically after endoscopic reduction: a case report. Surg Case Rep. 2016, 2:47. 10.1186/s40792-016-0175-0

11. Arima K, Hashimoto D, Takata N: Acute gastric volvulus in a patient with trisomy 21 . Surg Case Rep. 2015, 1:5. 10.1186/s40792-014-0005-1

12. Al-Naami MY: Gastric volvulus associated with traumatic diaphragmatic hernia: a delayed presentation. Ann Saudi Med. 1999, 19:137-8. 10.5144/0256-4947.1999.137

13. Lee HY, Park JH, Kim SG: Chronic gastric volvulus with laparoscopic gastropexy after endoscopic reduction: a case report. J Gastric Cancer. 2015, 15:147-50. 10.5230/jgc.2015.15.2.147

14. Atef M, Emna T: Bochdalek hernia with gastric volvulus in an adult: common symptoms for an original diagnosis. Medicine (Baltimore). 2015, 94:e2197. 10.1097/md.0000000000002197

15. Lin PY, Chang CC, Liu JD: A rare cause of periodic vomiting with hematemesis in a 36-yearold man. Gastroenterology. 2015, 149:870-1. 10.1053/j.gastro.2015.05.051

16. Masjedizadeh AR, Alavinejad P: Endoscopic view in a patient with acute gastric volvulus . Endoscopy. 2015, 47:e379-80. 10.1055/s-0034-1392501

17. Karthikeyan VS, Sistla SC, Ram D: Gastric volvulus following diagnostic upper gastrointestinal endoscopy: a rare complication. BMJ Case Rep. 2014, 10.1136/bcr-2013202833

18. Martínez-Pérez A, Garrigós-Ortega G: Perforated gastric volvulus due to incarcerated paraesophageal hernia. Rev Gastroenterol Mex. 2014, 79:204-6. 10.1016/j.rgmx.2014.04.002

19. Kosai NR, Gendeh HS, Noorharisman M: A case of closed loop small bowel obstruction within a strangulated incisional hernia in association with an acute gastric volvulus. Acta Medica (Hradec Kralove). 2014, 57:83-6. 10.14712/18059694.2014.45

20. Black TP, Verma LM: A twisted tale: chronic abdominal pain caused by gastric volvulus . Am J Med. 2014, 127 :e19-20. 10.1016/j.amjmed.2014.04.029

21. Altintoprak F, Yalkin O, Dikicier E: A rare etiology of acute abdominal syndrome in adults: gastric volvulus - cases series. Int J Surg Case Rep. 2014, 5:731-734.

10.1016/j.ijscr.2014.08.024

22. Kılınçalp S, Akinci H, Coban Ş: Successful treatment of acute gastric volvulus by emergency endoscopic reduction in a patient with cerebral palsy. Endoscopy. 2014, 46:e375-6. 10.1055/s0034-1377350

23. Lianos G, Vlachos K, Papakonstantinou N: Gastric volvulus and wandering spleen: a rare surgical emergency. Case Rep Surg. 2013, 561752. 10.1155/2013/561752 
24. Jeong SH, Ha CY, Lee YJ: Acute gastric volvulus treated with laparoscopic reduction and percutaneous endoscopic gastrostomy. J Korean Surg Soc. 2013, 85:47-50.

10.4174/jkss.2013.85.1.47

25. Ooka M, Kohda E, Iizuka Y: Wandering spleen with gastric volvulus and intestinal nonrotation in an adult male patient. Acta Radiol Short Rep. 2013, 2: 10.1177/2047981613499755

26. Sultan J, Vassallo PP, Davis P: Intermittent gastric volvulus secondary to gall bladder adhesions: a rare cause of gastric outlet obstruction. Hosp Med. 2005, 66:245.

10.12968/hmed.2005.66.4.18459

27. Kang DJ, D'Alessio M, Pan AS: Difficulties in diagnosing an intermittent mesenteroaxial gastric volvulus. J Surg Case Rep. 2013, 10:rjt078. 10.1093/jscr/rjt078

28. Warren C, Wallace W, Campbell WJ: Splenic laceration with a twist: a lesson learnt from gastric volvulus. Ann R Coll Surg Engl. 2012, 94:e88-9. 10.1308/003588412x13171221588974

29. Larssen KS, Stimec B, Takvam JA: Role of imaging in gastric volvulus: stepwise approach in three cases. Turk J Gastroenterol. 2012, 23:390-3. 10.4318/tjg.2012.0418

30. Nayak HK, Maurya G, Kapoor N: Delayed presentation of congenital diaphragmatic hernia presenting with intrathoracic gastric volvulus: a case report and review. BMJ Case Rep. 2012, 10.1136/bcr-2012-007332

31. Tabib SM, Assadipoya K, Mansorian R: Acute gastric volvulus presenting with gastric outlet obstruction and upper gastrointestinal bleeding. Turk J Gastroenterol. 2013, 24:293-5. 10.4318/tjg.2013.0546

32. Chen CT, Huang TW, Chang WK: Intrathoracic gastric volvulus. QJM. 2013, 106:963-4. 10.1093/qjmed/hcs177

33. Ghatak S: Gastric volvulus with diaphragmatic hernia presenting with unexplained weight loss: a delayed diagnosis. Singapore Med J. 2011, 52:e4-6.

34. Fansur M, Atiq S: Mesentro-axial gastric volvulus in a morgagni diaphragmatic hernia in an old female. J Coll Physicians Surg Pak. 2011, 21:299-300.

35. Kim HH, Park SJ, Park MI: Acute intrathoracic gastric volvulus due to diaphragmatic hernia: a rare emergency easily overlooked. Case Rep Gastroenterol. 2011, 5:272-277.

$10.1159 / 000328444$

36. Germanos S, Gourgiotis S, Saedon M: Severe abdominal pain as a result of acute gastric volvulus. Int J Emerg Med. 2010, 3:61-62. 10.1007/s12245-009-0136-5

37. Yakaryilmaz F, Banli O, Altun H: Delayed presentation of post-traumatic diaphragmatic hernia with gastric volvulus: a case report. Ulus Travma Acil Cerrahi Derg. 2010, 16:277-9.

38. Iso $\mathrm{Y}$, Tagaya $\mathrm{N}$, Nemoto $\mathrm{T}$ : Incarceration of a large cell neuroendocrine carcinoma arising from the proximal stomach with an organoaxial gastric volvulus through an esophageal hiatal hernia: report of a case. Surg Today. 2009, 39:148-52. 10.1007/s00595-008-3804-9

39. Singham S, Sounness B: Mesenteroaxial volvulus in an adult: time is of the essence in acute presentation. Biomed Imaging Interv J. 2009, 5:e18.

40. Sung HY, Cho SH, Sim SB: Congenital hemidiaphragmatic agenesis presenting as reversible mesenteroaxial gastric volvulus and diaphragmatic hernia: a case report. J Korean Med Sci. 2009, 24:517-9. 10.3346/jkms.2009.24.3.517

41. Woon YC, Chung YC: Delayed diagnosis of intermittent mesenteroaxial volvulus of the stomach by computed tomography: a case report. J Med Case Reports. 2008, 2:343. 10.1186/1752-1947-2-343

42. Coulier B, Broze B: Gastric volvulus through a Morgagni hernia: multidetector computed tomography diagnosis. Emerg Radiol. 2008, 15:197-201. 10.1007/s10140-007-0660-7

43. Testini M, Vacca A, Lissidini G: Acute intrathoracic gastric volvulus from a diaphragmatic hernia after left splenopancreatectomy: report of a case. Surg Today. 2006, 36:981-4. 10.1007/s00595-006-3281-y

44. Shriki JE, Nguyen K, Rozo JC: Rare chronic gastric volvulus associated with left atrial and mediastinal compression. Tex Heart Inst J. 2002, 29:324-328.

45. Matsuzaki Y, Asai M, Okura T: Ultrasonography of gastric volvulus: "peanut sign" . Intern Med. 2001, 40:23-7. 10.2169/internalmedicine.40.23 